Click www.researchjournal.co.in/online/subdetail.html to purchase.

Volume 5 | Issue 2 | September, 2014 | 125-132 — e ISSN-2231-6434 |

International Research Journal of Agricultural Economics and Statistics

Visit Us - www.researchjournal.co.in DOI : 10.15740/HAS/IRJAES/5.2/125-132

\title{
Research Paper Marketing of food-grains in Wardha district
}

\author{
V.O. BONDHARE, U.T. DANGORE, S.O. BONDHARE AND M.M. KADAM
}

See end of the paper for authors' affiliations

Correspondence to : V.O. BONDHARE

Department of Agricultural Economics and Statistics, College of Agriculture, Dr. Panjabrao Deshmukh Krishi

Vidyapeeth, AKOLA (M.S.) INDIA

\section{Paper History :}

Received : 01.02.2014;

Revised : 15.06.2014;

Accepted: 01.07.2014
ABSTRACT : Study was carried out on the producer's share in consumer rupee for food-grain marketing in Wardha district and problems faced by farmers in marketing. Data were collected from 120 cultivators for the year 2009-10 and secondary data were collected from various government publications for the period 1989-90 to 2008-09. All the major agencies involved in marketing of food-grain i.e. commission agent, wholesaler and retailer each 10 were selected the study. The food-grain selected for the present study are jowar, wheat, pigeonpea (tur) and chickpea (gram). The producer's share in consumer's rupee in case of jowar was highest 96.19 per cent in channel-I followed by channel-II and channel-III. The producer's share in consumer's rupee in case of wheat was highest 97.33 per cent in channel-I. The producer's share in consumer's rupee was highest 99.07 per cent in case of Tur in channel-I followed by channel-II and channel-III. The producer's share in consumer's rupee was highest Rs.98.43 in case of gram in channel-I followed by channel-II and channel-III.

KEY WORDS : Marketing of foodgrain, Price spread of food grain, Market margin of food grain

HOW TO CITE THIS PAPER : Bondhare, V.O., Dangore, U.T., Bondhare, S.O. and Kadam, M.M. (2014). Marketing of food-grain in Wardha district, Internat. Res. J. Agric. Eco. \& Stat., 5 (2) : 125-132. 